\title{
PENGGUNAAN BAHASA YAMDENA DI PULAU YAMDENA BAGIAN TIMUR KABUPATEN KEPULAUAN TANIMBAR PROVINSI MALUKU
}

\author{
Isak Samangun \\ Romilda Arivina da Costa \\ Elsa Latupeirissa \\ Universitas Pattimura \\ email:chaksamangun30@gmail.com
}

\begin{abstract}
Abstrak: Berdasarkan penelusuran dokumentasi yang ditemukan ada lima bahasa di Kepulauan Tanimbar, di antaranya bahasa Yamdena, Selaru, Fordata, Makatian dan Seluasan. Namun, yang dibahas oleh peneliti adalah penggunaan bahasa Yamdena di Pulau Yamdena Bagian Timur. Yamdena Bagian Timur terdapat enam belas desa, namun peneliti hanya memilih empat lokasi sebagai tempat penelitian yaitu, Desa Arma, Arui Bab, Arui Das dan Sifnana. Teori yang digunakan dalam penelitian ini adalah teori kontak bahasa dan pergeseran bahasa. Ada pun hasil yang ditemukan yaitu secara umum penggunaan bahasa Yamdena di Pulau Yamdena Bagian Timur sudah bergeser karena ada beberapa faktor yang mempengaruhinya yaitu, faktor lingkungan, teknologi informasi dan komunikasi serta faktor pemukiman penduduk yang begitu padat.
\end{abstract}

Kata Kunci: Penggunaan bahasa Yamdena, Pergeseran, dan kontak bahasa. 
Yamdena Language Usage in Yamdena Island Eastern

District of Tanimbar Islands Regency Maluku Province

\author{
Isak Samangun \\ Romilda Arivina da Costa \\ Elsa Latupeirissa \\ Universitas Pattimura \\ email:chaksamangun30@gmail.com
}

\begin{abstract}
Based on the exploration of abstract documentation found there are five languages in the Tanimbar Islands, including Yamdena, Selaru, Fordata, Makatian, and Extensive use of languages. Yamdena in East Yamdena Island, East Yamdena, there are six fillages, but researches only chose four locations as research sites, namely Arma Village, Arui Bab, Arui Das and Sifnana. Theories used in this research are the theory of language contact language shift. There are also result found that in general the use of the Yamdena language in Eastren Yamdena Island has shifted because there are several factors that influence it, namely the environmental factors of information and communication technology as well as the dense population settlement factors. But what is discussed by research is.
\end{abstract}

Keywords: Yamdena language usage, Shifting, and language contact 


\section{A. PENDAHULUAN}

Bangsa Indonesia adalah bangsa yang multietnis. Dikatakan demikian karena bangsa Indonesia terdiri dari beraneka ragam suku, budaya, dan bahasa. Salah satu bahasa daerah yang masih hidup di antaranya adalah bahasa Yamdena (BYM). Bahasabahasa di Kepulauan Kei dan Tanimbar terbagi hampir secara merata di antara kedua kelompok pulau tersebut, tiga di Kei dan empat di Tanimbar. ketujuh-tujuhnya tergolong dalam rumpun bahasa Austronesia (Pusat Pengkajian dan Pengembangan Maluku Universitas Pattimura dan Summer Institute of Linguistics 1996 : 83), sedangkan menurut penelitian terkini yang dilakukan oleh Romilda da Costa dan Mariana Lewier (2012) menemukan bahwa di Kepulauan Tanimbar terdapat lima bahasa dan penambahannya adalah bahasa Makatian. Yamdena Bagian Timur terdapat enam belas desa, namun peneliti hanya mengambil empat desa sebagai lokasi penelitian yaitu Desa Arma, Arui Bab, Arui Das dan Sifnana di karenakan posisi geografis dan situasi kebahasaan yang berbeda._Lokasi penelitian ini dipilih karena posisi geografis yang berbeda yaitu jarak antara keempat lokasi penelitian. Situasi kebahasan yang berbeda yaitu penggunaan bahasa oleh masyarakat Desa Arma yang dominannya adalah bahasa Melayu Ambon. Situasi yang mirip dengan masyarakat yang ada di Desa Sifnana, namun pergeserannya tidak sejauh masyarakat Arma. Berbeda lagi dengan masyarakat tutur yang berada di Desa Arui Bab dan Arui Das yang penggunaan bahasa Yamdena lebih dominan dalam kehidupan sehari-hari untuk berkomunikasi. Namun, kedua masyarakat penutur bahasa Yamdena yang berada di Desa Arui Bab dan Arui Das penggunaan bahasa Yamdena pada Desa Arui Das lebih menonjol.

Berdasarkan penjelasan di atas, nampak bahwa penggunaan bahasa Yamdena bukan saja dituturkan oleh masyarakat penutur bahasa yang berada di Yamdena Bagian Timur, tetapi dituturkan juga oleh masyarakat Pulau Selaru (Desa Adaut). Pulau Selaru terdiri dari enam desa, yaitu: Desa Adaut, Kandar, Lingat, Fursui, Eliasa, dan Namtabung. Jika dilihat dari letak geografis, Pulau Selaru terpisah dari Pulau Yamdena dan memiliki bahasa tersendiri kecuali Desa Adaut yang masyarakatnya menggunakan bahasa Yamdena. Namun, dari keenam desa yang sudah disebutkan di atas, terdapat lima desa yang hanya menggunakan bahasa Selaru di antaranya yaitu, Desa Kandar, Lingat, Fursui, Eliasa, dan Namtabung. Sementara Desa Adaut sendiri tidak menggunakan bahasa Selaru untuk berkomukasi, justru bahasa yang mereka gunakan adalah bahasa Yamdena. Hal ini didasarkan pada kenyataan hidup bahwa masyarakat Desa Adaut adalah sebagian dari masyarakat Tanimbar dalam hal ini Yamdena Timur yang hidupnya kawin campur dan kemudian berdomisili dan menetap di Pulau Selaru khususnya Desa Adaut.

Oleh sebab itu, kedudukan dan fungsi bahasa Yamdena cukup berkembang dengan adanya kehidupan masyarakat tutur yang ada di Pulau Yamdena dan sebagian masyarakat Pulau Selaru (Desa Adaut), karena kedudukan bahasa Yamdena sebagai bahasa daerah dan sebagai lambang kebanggaan daerah, lambang identitas daerah, dan alat penghubung di dalam keluarga dan masyarakat Tanimbar serta sebagai alat komunikasi pemerintah daerah. Sedangkan fungsinya adalah sebagai pendukung bahasa nasional, sebagai bahasa pengantar di sekolah dasar, sarana pendukung dan kebudayaan Tanimbar. Akan tetapi, dalam perkembangannya bahasa Yamdena diperhadapkan dengan berbagai macam tantangan, salah satunya adalah perkembangan ilmu pengetahuan dan teknologi yang menyebabkan penggunaan bahasa Yamdena pada kalangan orang tua cukup berkembang, sementara untuk generasi mudah bahasa Yamdena 


\section{B. METODE PENELITIAN}

Penelitian ini dirancangkan dengan menggunakan pendekatan kualitatif yang juga memanfaatkan beberapa aspek dari pendekatan kuantitatif. Rancangan penelitian kualitatif yang digunakan adalah penelitian kualitatif deskriptif yang menghasilkan data deskriptif berupa kata-kata tertulis atau lisan dari orang-orang atau perilaku yang dapat diamati. Penelitian kualitatif lebih menghendaki agar pengertian dan hasil interprestasi yang di peroleh di rundingkan dan disepakati oleh manusia yang dijadikan sebagai sumber data. Meskipun data dalam analisis kualitatif bukanlah data berupa angka-angka (data kuantitatif), pada hakikatnya analisis tidak tertutup kemungkinan analisis kualitatif memanfaatkan data kuantitatif, untuk kepentingan (a) pengembangan analisis data kualitatif itu sendiri dan tentunya penggunaan data tersebut sampai batas tertentu sesuai dengan kebutuhan; (b) karena sifat data kuantitatif itu kaku dan belum bermakna, maka pada saat penggunaannya harus dilakukan secara luwes dan memaknainya sebagaimana yang diinginkan dalam kaidah-kaidah penelitian kualitatif; (c) penggunaan data kuantitatif sekaligus mempertajam sekaligus memperkaya analisis kualitatif itu sendiri. Untuk penelitian bahasa misalnya, data yang dimaksud adalah jumlah penutur suatu bahasa atau varian, jumlah informan yang memilih dialek tertentu dalam menjawab kuesioner, jumlah informan yang memilih jawaban tertentu sesuai sesuai dengan variabel penelitian: usia atau ketokohan dan gender, data jumlah batas alam, volume batas alam: tinggi gunung lebar jalan dan lainya (Mahsun, 2005: 233).

Data dalam penelitian ini adalah Penggunaan bahasa Yamdena oleh masyarakat penutur bahasa Yamdena dengan kategori umur yang digunakan istilah generasi muda (GM), generasi transisi (GT) dan generasi lanjut (GL) di Desa Arma, Arui Bab, Arui Das dan Sifnana di Pulau Yamdena Bagian Timur, Kabupaten Kepulauan Tanimbar. Sedangkan penggunaan bahasa Yamdena oleh masyarakat penutur bahasa Yamdena di Pulau Yamdena Bagian Timur pada ranah keluarga, pendidikan (sekolah), pekerjaan, ketetanggaan, dan ranah keakraban. Teknik pengumpulan data dalam penelitian ini adalah teknik angket atau kuesioner, observasi, wawancara, pencatatan dan pendokumentasian. Menurut Miles dan Huberman (dalam Moleong, 2017: 248) mengemukakan bahwa teknik analisis data adalah proses mencari dan menyusun secara sistematis data yang diperoleh dari hasil wawancara, pencatatan lapangan, dan pendokumentasian, serta alat perekam dengan cara mengorganisasikan data ke dalam pola, mengidentifikasi hal-hal penting yang akan dipelajari, dan membuat kesimpulan sehingga mudah dipahami oleh peneliti dan pembaca. Dengan teknik analisis di atas, maka peneliti membuat langkah-langkah dalam menganalisis data sesuai dengan kebutuhan peneliti, yakni (i) mengumpulkan data dari informan melalui hasil observasi, wawancara, pencatatan lapangan, dan pendokumentasian; (ii) memilih data yang diperlukan sesuai dengan pokok penelitian; (iii) mengidentifikasi hasil tabulasi data, kemudian dipersentasikan. Setelah itu, hasil persentasi tersebut dideskripsikan, diinterpretasikan dan dianalisis; (iv) menarik kesimpulan. 


\section{PEMBAHASAN}

\section{Kekerapan Penggunaan BYM di Desa Arma}

Hasil persentase yang terlihat pada diagram 1.1 untuk penggunaan BYM di Desa Arma 35\%, BMA 65\%, dan BI 0\%. Penggunaan BYM hanya tersisa 35\% hanya digunakan oleh GL dan sebagain dari penutur GT. Biasanya BYM ini digunakan oleh GT dan GL pada saat kerja bakti di desa, saat duduk dengan tetangga rumah dan saat kerja bakti di kebun. Sedangkan untuk GM, mereka cenderung menggunakan BMA Penggunaan BMA. Hal ini terjadi karena tingkat penguasaan BYM masih relatif kurang. Kelebihannya mereka dapat memahami apa yang disampaikan oleh penutur yang sementara berbicara, namun untuk meresponnya itu biasanya mereka menggunakan BMA. Karena sekarang ini GM lebih bangga atau suka menggunakan bahasa lain dibandingkan dengan bahasa mereka sendiri yaitu BYM. Bahasa ini digunakan ketika seorang penutur yang berasal dari Desa Arma bertemu dengan penutur yang berasal dari desa lain. Alasan lain yaitu, ketika mereka pergi ke Larat atau Saumalaki untuk berbelanja kebutuhan sehari-hari biasanya bahasa yang digunakan adalah BMA. Hal ini terjadi karena lawan tutur mereka itu bukan berasal dari desa atau daerah tersebut. Penggunaan BMA ini digunakan supaya lawan tutur kita bisa memahami apa yang nantinya disampaiakan serta untuk menjalin alur komunikasi yang baik antara penutur dan lawan tutur.

Berdasarkan teknik FGD yang diterapkan, maka hasil yang ditemukan terkait penggunaan BYM di Desa Arma khususnya dalam keluarga, biasanya BYM diajarkan atau difungsikan melalui kegiatan bercerita atau deklaratif dan kegiatan menyuruh atau direktif. Bercerita yang dimaksud itu seperti, ketika orang tua sementara duduk bersama dengan anak-anak, biasanya orang tua menceriterakan pengalaman-pengalaman hidup di masa lalu atau bisa juga cerita-cerita rakyat yang berasal dari desa atau daerah setempat. Oleh karena itu, penutur GM tidak lagi berkomunikasi dengan menggunakan BYM tetapi mereka lebih dominan menggunakan BMA untuk berkomunikasi antara sesama keluarga bahkan teman sebaya.

Pembelajaran bahasa pertama dalam hal ini BYM, seharusnya digunakan dalam komunikasi dengan anak-anak di rumah. Namun, para penutur justru mengarahkan upaya pelestarian atau penggunaan BYM melalui sekolah dan berharap ada guru yang dilatih secara khusus untuk mengajarkan BYM dalam muatan lokal, tetapi sampai saat ini belum berjalan sesuai yang diharapkan karena belum ada tenaga pendidik yang bersedia atau memberanikan diri untuk mengajarkan bahasa tersebut.

\section{Kekerapan Penggunaan BYM di Desa Arui Bab}

Penggunaan BYM di Desa Arui Bab yang sudah tergambar pada diagram 1.1 memperlihatkan hasil persentase untuk BYM 43\%, BMA 57\% dan BI 0\%. Jika dibandingkan dengan penggunaan BYM di Desa Arma yang mencapai 35\%, sementara di Desa Arui Bab mengalami peningkatan menjadi 43\% dangan selisih 8\%. Hal ini 
menunjukan bahwa penggunaan BYM yang hanya terjalin antar sesama orang tua, sementara GM lebih dominan menggunakan BMA. Bahasa tersebut sering sekali dipakai atau digunakan dalam komunikasi sehari-hari antara tetangga yang satu dengan tetangga yang lain, saat adanya pertemuan atau pengurusan di desa tersebut, dan saat berpergian ke kebun atau ke hutan.

Penggunaan BMA lebih dominan karena kurang adanya kegairaan dan kebanggan dalam berbahasa Yamdena, kurang adanya perhatian orang tua untuk mengajarkan bahasa daerah kepada anak-anak. Faktor-faktor inilah yang menyebabkan hingga tinggkat penguasaan dalam penggunaan BYM kurang berkembang. Oleh karena itu, mereka lebih bangga atau suka menggunakan BMA dibandingkan bahasa mereka sendiri. Padahal mereka lupa bahwa, manfaat bahasa daerah ini sangat penting dan ini juga menjadi ciri khas mereka sendiri. Bahasa ini juga digunakaan saat masyarakat dari Desa Arui Bab yang pergi ke Saumlaki. Ketika tiba di Saumlaki sudah pasti bahasa yang digunakan adalah BMA, Itu juga ketika bebrbelanja di toko atau kios, karena lawan tutur mereka berasal dari desa atau daerah yang berbeda. Tetapi ketika pemilik toko atau kios itu berasal dari desa atau daerah yang sama, sudah pasti komunikasinya berlangsung dengan menggunakan bahasa daerah kalau penutur dan lawan tuturnya sesama orang tua. Sedangkan penggunaan BI digunakan oleh masyarakat Arui Bab pada saat adanya kunjungan-kunjungan formal, seperti kunjungan pegawai perikanan untuk mensosialisasikan tentang cara menangkap, merawat dan mendistribusi ikan ke berbagai daerah.

Dari hasil diskusi dalam FGD para penutur GT pada umunya menerapkan cara bercerita atau deklaratif dan menyuruh atau direktif dalam kegiatan sehari-hari menggunakan BYM. Diharapkan cara tersebut bisa membuat anak-anak dalam hal ini sebagai penutur GM bisa menggunakan BYM untuk berkomunikasi dengan anggota keluarga atau masyarakat pada umumnya. Justru cara tersebut sama sekali tidak mempengaruhi GM untuk tetap menggunakan BYM, tetapi mereka lebih suka menggunakan BMA untuk berkomunikasi antara sesama dibandingkan BYM.

Cara yang diterapkan oleh orang tua itu sama sekali tidak menimbulkan afek apa pun bahkan tidak bisa menjamin kelak nanti GM bisa seutuhnya fasih dalam menggunakan BYM atau tidak. Oleh sebab itu, pelestarian BYM diarahakan oleh pemerintah desa ke pihak sekolah untuk melestarikannya. Namun sampai saat ini belum ada pelestarian BYM dari pihak sekolah karena belum ada tenaga pendidik khusus yang bisa mengajarkan BYM di sekolah melalui muatan lokal. Saat ini, belum ada upaya dari pemerintah desa terkait pelestarian BYM. Namun, biasanya upaya tersebut disampaikan dalam bentuk lisan. Lisan yang dimaksud adalah penyampaiannya hanya melalui toa kepada seluruh masyarakat bahwa harus menggunakan BYM untuk berkomunikasi dalam keluarga secara khusus dan masyarakat pada umumya 


\section{Kekerapan Penggunaan BYM di Desa Arui Das}

Diagram 1.1 memperlihatkan penggunaan BYM di Desa Arui Das 46\%, BMA 53\% dan BI 0\%. Tidak bisa dipungkiri bahwa penggunaan BYM yang lebih dominan atau lebih banyak digunakan terdapat oleh masyarakat tutur di Desa Arui Das dibandingkan ketiga desa lainya yaitu Arma, Arui Bab dan Sifnana. Faktor yang menyebabkan sehingga masyarakat tutur yang berbahasa yamdena lebih dominan karena posisi atau letak geografis desa tersebut jauh dari pusat kota dan berada di atas pegunungan sehingga bahasanya kurang terkontaminasi. Bahasa ini biasanya digunakan oleh GL saat adanya pertemuan kelompok-kelompok kerja, seperti kelompok tani, dan kelompok nelayan. Digunakan juga saat berkomunikasi antartetangga, saat adanya pertemuan-pertemuan di desa antara kepala desa dan masyarakat serta saat adanya upacara-upcara adat. BMA digunakan saat adanya masyarakat pendatang yang berasal dari desa lain untuk menanyakan alamat rumah atau bisa saja letak kantor desa. Bahasa ini juga sering sekali dipakai oleh masyarakat setempat saat berkunjung ke Kota Kabupaten untuk berbelanja atau mengurus surat-surat yang berhubungan dengan kebutuhan mereka. Sementara penggunaan BI biasanya digunakan saat adanya pertemuan-pertemuan formal yang biasanya melibatkan perangkat desa dengan petugaspetugas yang berasal dari Kecamatan atau Kabupaten Kota terkait dengan pengembangan dan kemajuan desa tersebut. Bahasa ini juga digunakann saat adanya kunjungan pegawai kesehatan atau dinas pendidikan untuk sosialisasi tentang kesehatan dan pendidikan kepada masyarakat.

Berdasarkan teknik FGD yang diterapkan, maka hasil yang ditemukan terkait penggunaan BYM di Desa Sifnana khususnya dalam keluarga, biasanya BYM diajarkan atau difungsikan melalui kegiatan bercerita atau deklaratif dan kegiatan menyuruh atau direktif. Bercerita yang dimaksud itu seperti, ketika orang tua sementara duduk bersama dengan anak-anak, biasanya orang tua menceriterakan pengalaman-pengalaman hidup di masa lalu atau bisa juga cerita-cerita rakyat yang berasal dari desa atau daerah setempat. Oleh karena itu, penutur GM hanya bisa memahami apa yang disampaiakan oleh orang tua namun untuk merespon biasanya mereka lebih suka menggunakan BMA. Sebenarnya mereka bisa menggunakan bahasa tersebut namun belum terlalu fasih dan penyampaiannya hanya dalam bentuk kalimat yang pendek-pendek.

Sejalan dengan penjelasan di atas, maka penutur GT yang bekerja di kantor desa menghimbau agar lebih baiknya BYM diajarkan di sekolah supaya secara tidak langsung sudah melestarikannya serta membiasakan GM untuk memahaminya sejak dini. Namun, sampai saat ini belum terealisai karena tidak ada tenaga pendidik khusus untuk mengajarkan bahasa tersebut. Hal inilah yang menyebabkan sehingga GM belum bisa menggunakan BYM untuk berkomunikasi secara fasih, karena pembelajaran BYM pertama di rumah tidak terlaksana dengan baik diakibatkan kesibukan orang tua yang begitu banyak, sehingga menyebabkan anak-anak lebih suka bermain game di hp dibandingkan belajar dan di tambah lagi pembelajaran muatan lokal di sekolah-sekolah 
belum terlaksana dan berjalan sesuai yang diharapkan. Oleh karena itu, BYM hanya digunakan oleh sesama orang tua dalam hal ini GT dan GL. Sedangkan GM cendrung menggunakan BYM karena proses pembelajarannya tidak berjalan secara efektif disebabkan kesibukan orang tua.

Upaya pemerintah desa terkait pelestarian BYM hanya dalam bentuk lisan seperti yang sudah di sebutkan di Desa Arui Bab, dan sejauh ini belum ada tindakan konkret atau nyata terkait pelestarian bahasa tersebut. Oleh sebab itu tak bisa dipungkiri bahwa, sampai saat ini BYM masih tetap digunakan oleh GL karena menurut mereka bahasa tersebut harus dilestarikan secara turun-temurun. Namun sangat memprihatinkan karena penutur GM lebih bangga menggunakan BMA dibandingkan bahasa mereka sendiri.

\section{Kekerapan Penggunaan BYM di Desa Sifnana}

Penggunaan BYM di Desa Sifnana 33\%, BMA 56\% dan BI 1\%. Jika dilihat dari letak geografis desa tersebut berada dalam pusat Kota Kabupaten sehingga penggunaan BYM mulai sedikit bergeser dikarenakan tingkat mobilitas penduduk cukup banyak. Bahasa tersebut biasanya digunakan saat komunikasi antara sesama orang tua, para tetangga, upacara adat (panas pela) dan saat di kantor desa. Tidak bisa dipungkiri penggunaan BMA lebih dominan karena perkembangan kota yang semakin pesat, membuat masyarakat tutur juga cepat untuk terkontaminasi dengan bahasa-bahasa lain. Jika dilihat, desa yang berada paling jauh dari pusat kota penggunaan BMA melambung tinggi persentasenya apalagi dibandingkan dengan Desa Sifnana yang letaknya di jantung atau pusat kota.

Menurut pengakuan dari bapak kepala desa Sifnana, penggunaan BI ini tidak digunakan saat adanya jam kantor. Bahasa tersebut digunakan ketika ada pegawaipegawai dari dinas pendidikan yang berkunjung ke kantor desa, namun selepas itu dalam kegiatan sehari-hari mereka lebih banyak menggunakan BYM untuk berkomunikasi antarsesama staf desa. Hal ini menunjukan bahwa mereka lebih menjunjung tinggi keberadaan BYM, namun disisi lain bahasa tersebut sedikit terancam karena pengaruh kota yang nantinya membuat masyarakat tutur cepat terkontaminasi dengan bahasa-bahasa lain.

Oleh karena itu dapat disimpulkan bahwa, secara umum penggunaan BMA lebih dominan di pakai oleh masyarakat tutur yang berada di Yamdena Bagian Timur, Kabupaten Kepulauan Tanimbar dibandingkan BYM dan BI. Meskipun demikian tidak mengurangi kesadaran masyarakat Desa Arma, Arui Bab, Arui Das dan Sifnana untuk tetap menggunakan serta mempertahankan bahasa daerah mereka.

Dari hasil diskusi dalam FGD para penutur GT pada umunya mengatakan bahwa di rumah BYM difungsikan secara deklaratif dan direktif. Deklaratif yang dimaksud adalah pembelajarannya melalui cara bercerita, seperti bercerita tentang pengalama- 
pengalaman masa lalu kepada anak-anak. Sedangkan direktif yaitu cara menyuruh melalui kegiatan sehari-hari. Cara tersebut dilakukan agar adanya pembiasaan terhadap pembelajaran BYM kepada GM agar kelak mereka bisa menggunakannya untuk berkomunikasi.

Sekalipun cara tersebut sudah di terapkan di rumah, namun tidak mempengaruhi GM untuk tetap mempertahankan bahasa tersebut. Justru mereka memperlihatkan penggunaan BMA lebih dominan dibandingkan BYM. Oleh sebab itu, pemerintah menganjurkan agar BYM diajarkan di sekolah-sekolah agar secara tidak langsung sudah menumbuhkan kepada mereka secara dini. Namun sampai saat ini belum terlaksana dengan baik karena tidak ada tenaga pendidik khusus untuk mengajarakan BYM. Ketidakberanian tenaga pendidik untuk mengajarakan BYM di sekolah karena ada beberapa kosakata belum ada terjamahan ke dalam BYM, seperti ucapan selamat pagi, selamat siang, selamat sore dan selamat malam.

Disisi lain, pemerintah desa setempat hanya menghimbau dan menginformasikan agar BYM digunakan dalam aktivitas sehari-hari tetapi tidak memiliki ide konkret yang dapat direalisasikan dalam kerja sama dengan masyarakat penuturnya, kecuali pembentukan sanggar atau tari untuk mengajarkan BYM dalam rangkaian gerak atau nyanyian untuk pengiring tari-tarian tersebut. Padahal, tindakan ini pun sepertinya tidak efektif sebab yang meminati kegiatan seperti ini hanya segelintir orang dari GM dan yang menguasai tarian dan nyanyian kebanyakan GT dan GL.

Analisis ini menggunakan teori penggunaan bahasa untuk membandingkan situasi penggunaan bahasa dari masing-masing lokasi penelitian secara umum dengan menggunakan teori kontak bahasa yaitu suatu keadaan dimana adanya interaksi antara dua atau banyak bahasa yang berbeda latar belakang digunakan dalam satu situasi yang mengakibatkan suatu bahasa berpengaruh pada bahasa yang lain, dan memungkinkan terjadinya pergantian pemakaian bahasa oleh penutur sesuai konteks sosialnya. analisis ini juga menggunakan teori pemertahanan karena dilihat dari diagram 1.1 dan penjelasan di atas memperlihatkan penggunaan BMA yang lebih dominan. Meskipun demikian, tidak mengurangi kesadaraan serta kebanggaan dalam berbahasa oleh masyarakat tutur di masing-masing lokasi penelitian untuk tetap mempertahankan BYM dalam kehidupan sehari-hari.

\section{Kekerapan Penggunaan BYM pada Ranah Keluarga}

Penelitian yang dilakukan di Desa Arma, Arui Bab, Arui Das, dan Sifnana berorientasi pada ranah keluarga. Ranah ini dominan dibahas karena merupakan basis utama sekaligus pertahanan terakhir dalam persoalan pemertahanan suatu bahasa. Yang dimaksud dengan ranah keluarga adalah proses terjadinya peristiwa komunikasi yang berlangsung antara ayah dan ibu, ayah dan anak atau pun kakak dan adik. 
Kekerapan penggunaan BYM di Desa Arma pada ranah keluarga dianalisis berdasarkan umur penutur dari (GM 12-25), (GT 25-50) dan (GL >51 tahun). Hasil persentase penggunaan BYM bisa dilihat pada tabel 4.14. Penggunaan BYM pada ranah keluarga bagi penutur GM dengan hasil persentase BYM 62\%, BMA 38\% dan BI $0 \%$. Berdasarkan hasil persentase tersebut, peneliti akan menggambarkan alur penggunaan BYM ketika penutur berada di rumah saat berlangsungnya komunikasi antaranggota keluarga. Berikut ini adalah proses komunikasi antaranggota keluarga dengan menggunakan BYM, misalnya komunikasi yang terjalin antara (H.S) bersama istrinya (H.J) dengan topik percakapan hasil kerja kebun. Percakapan dituturkan dalam kalimat berikut :

(H.S) : Ellen, awatin yei to rais

'Keladi yang ditanam hasilnya kurang baik

(E.J) : Ma tos fermpei, fernei motak ndre artinya

'Mau bagaimana kalau hasilnya sudah seperti itu.

Percakapan di atas memiliki hubungan timbal balik dan berjalan lancar karena bapak Hendrik menggunakan BYM untuk menyampaikan suatu maksud kepada istrinya dan istrinyapun membalas percakapan tersebut dengan menggunakan BYM. Percakapan ini berlangsung lancar dengan baik karena penutur dan lawan tutur sama-sama memahami bahasa Yamdena karena berasal dari desa yang sama. Penggunaan BMA terjadi di rumah ketika penutur dalam hal ini (H.S) berkomunikasi dengan anaknya (A.S) dengan topik percakapan tentang panjualan hasil kebun di pasar. Percakapannya dituturkan dalam kalimat berikut :

(H.S) : Nus, tadi bapa dong pi jual sayor dapa seratus lima puluh ribu

'Nus, hasil penjualan sayur hari ini berjumlah seratus lima puluh ribu rupiah'

(A.S) : Bagus to bapa, besok beta pipeti lai lalu bapa pi jual e

'Baik Ayah, besok saya akan pergi untuk memetik kembali agar Ayah segera pergi untuk menjualnya.

(H.S) : Besok peti banya sadiki barang akang paling lako

'Ambil yang banyak karena laris terjual'

(N) : Iyo bapa 'Iya Ayah'

Komunikasi yang terjalin antara orang tua dan anak ini menggunakan BMA dan bahasa tersebut dituturkan oleh bapak (H.S) terkait hasil penjualan hasil kebun disampaikan kepada anaknya Anus Samangun. Anak tersebut memahami maksud dan tujuan dari penyampaian ayahnya dengan menggunakan bahasa tersebut. Komunikasi berlangsung saat mereka sementara duduk bersama di rumah, sedangkan penggunaan BI sama sekali tidak ditemukan pemakaiannya dalam ranah keluarga. Penggunaan BYM pada ranah keluarga bagi penutur GT dengan hasil persentase BYM 35\%, BMA 65\% dan BI $0 \%$. Hasil persentase ini peneliti akan menggambarkan situasi kebahasaan yang terjadi ketika penutur berada di rumah. misalnya, komunikasi yang terjalin antara bapak (N.D) dengan istrinya (R.M) tentang makan hasil kebun baru di bulan agustus. Percakapannya dituturkan dalam kalimat berikut :

(N.D) : Rap mubutin awatin lo nde tat 
(R.M) :Nasaf

'Apakah anda sudah mengumpulkan keladi atau belum'?

(N.D) : Na arin yon de

'Untuk apa'

'Di arin yang kita tempati'

(R.M) : Lon fukit, nose betko kti ma kbutin ndre

'Saya belum kumpul hasil tetapi nanti akan saya kumpulkan'

Komunikasi berlangsung antara penutur dan lawan tutur dengan menggunakan

BYM, karena penutur dan lawan tutur sama-sama mengerti dan memahami maksud yang disampaikan. Komunikasi terjadi di rumah ketika penutur dan lawan tutur lagi duduk di teras rumah .Penggunaan BMA terjadi ketika teman dari ibu Rahap yang berprofesi sebagai seorang guru berkunjung ke rumahnya untuk menawarkan beasiswa kepada anaknya yang sebentar lagi akan menamatkan sekolah menengah pertama dan melanjutkan ke sekolah menengah atas. Percakapannya dituturkan dalam kalimat berikut :

(I.G) : Rap, beta datang kemari mau bilang Sina lah mendaftar beasiswa

'Saya kemari ingin menawarkan beasiswa kepada anak anda'

(I.R) : Beasiswa apa lah

'Jenis beasiswa apa yang anda tawarkan'

(I.G) : Beasiswa orang tua seng mampu

'Beasiswa kepada anak-anak yang orang tuanya tidak mampu'

(I.R) : Kalo bagitu dia iko jua, tapi perlu apa saja supaya beta suru dia siapkan 'Anak saya akan ikut namun apa saja yang perlu atau harus disiapkan agar nanti saya samapaikan kepadanya'

(I.G) : Yang harus dia siap itu, kartu keluarga, deng buat surat keterangan orang tua seng mampu dari desa

'Berkas-berkas yang harus disiapkan adalah kartu keluarga serta surat keterangan orang tua tidak mampu dari pemerintah desa'

(I.R) : Iyo suda nanti beta bilang di dia. Trima kasih banyak-banyak lai

'Iya, nanti saya akan sampaikan maksud tersebut kepada anak saya dan sebelumnya saya ucapkan terima kasih'

(I.G) : Sama-sama.

Komunikasi yang terjalin antara (I.G) dan (I.R) di rumah ketika penutur dalam hal ini Ibu Guru berkunjung ke rumah lawan tutur untuk menawarkan suatu maksud yang sudah dijelaskan pada percakapan di atas. Percakapan berlangsung dengan baik karena penutur menanyakan beberapa hal kepada lawan tutur dengan menggunakan BMA sehingga lawan tutur merespon dengan menggunakan bahasa yang sama. Penggunaan BYM pada ranah keluarga bagi penutur GL dengan hasil persentase $74 \%$, BMA $26 \%$ dan BI 0\%. Hasil persentase ini, peneliti akan menggambarkan situasi penggunaan bahasa yang terjadi antara angota keluarga saat di rumah. misalnya komunikasi yang terjalin antara nenek (D.J) dengan anaknya (M.J) tentang perkawinan cucunya yang bernama Ulis anak dari bapak Melkias dengan menggunakan BYM. Percakapannya dituturkan dalam kalimat berikut :

(N.D) : Meki nose rafsau e ramin mbei

'Dimanakah mereka akan tinggal saat bersatu nanti'?

(M) : Ramin na kenjap yei motak ndre

'Mereka akan tinggal di rumah ini' 
(N.D) : Mfualak ber sir lo nde tat

'Apakah anda sudah sampaiakan hal ini kepada mereka atau belum'

(M) : Yak falik ber sir lo nde, lah sir nyodin low

'Saya sudah sampaiakan kepada mereka dan mereka juga sudah setuju'

Komunikasi tersebut terjadi ketika Ibu (D.J) sementara duduk dengan anaknya yaitu (M.J) di dalam rumah sambil nonton. Tiba-tiba Penutur dalam hal ini Ibu (D.J) teringat dengan cucunya yang sebentar lagi akan menikah, maka dengan hal itu secara spontan dia langsung menanyakannya dengan menggunakan BYN dan anaknya pun merespon dengan bahasa yang sama. Percakapan yang terjadi antara keduanya berlangsung dengan baik karena keduanya sama-sama fasih dalam menggunakan bahasa tersebut.

Berdasarkan penjelasan di atas terkait penggunaan bahasa yang terjadi pada ranah keluarga di Desa Arma, penjelasan tersebut peneliti analisis dengan menggunakan teori ranah atau domain yaitu hubungan antarkomunikator dengan tempat terjadinya peristiwa komunikasi sesuai struktur sosial lapisan masyarakat. Sebab, percakapan atau komunikasi berlangsung saat penutur dan lawan tutur berada di rumah. Teori kedua yang peneliti gunakan untuk menganalisis adalah pergeseran dan pemertahanan. Pergeseran adalah masalah penggunaan bahasa oleh seorang penutur atau sekelompok penutur yang terjadi sebagai akibat perpindahan dari satu masyarakat tutur ke masyarakat tutur lain. Pergeseran terjadi bagi penutur generasi muda (12-25 tahun), yang diakibatkan kurang adanya perhatian orang tua terhadap anak-anak mereka dalam proses pembelajaran BYM. sedangkan pemertahanan bahasa yaitu usaha masyarakat untuk tetap menggunakan bahasa pertama sebagai identitas kelompok. Pemertahanan bahasa pada ranah keluarga ini terlihat pada generasi transisi dan generasi lanjut, mereka lebih banyak menggunakan bahasa Yamdena untuk berkomunikasi antar anggota keluarga dibandingkan bahasa Melayu Ambon dan bahasa Indonesia.

\section{Kekerapan Penggunaan BYM pada Ranah Keluarga}

Kekerapan penggunaan BYM pada ranah keluarga bagi penutur GM dengan hasil persentase 7\%, BMA 93\% dan BI 0\%. BYM biasanya digunakan oleh GM pada saat berada di rumah antara anak dan orang tua, seperti dituturkan dalam kalimat berikut

(A) : Fin, mwal sensilai ne ber bap fukit?

'Fin tolong ambilkan parang untuk ayah'?

(F) : Monin bap

'baik ayah'.

Komunikasi yang terjalin antara ayah dan anak di rumah dengan menggunakan bahasa daerah merupakan suatu pembelajaran atau pewarisan bahasa kepada anak-anak, agar nantinya ke depan mereka sudah bisa menggunakannya untuk berkomunikasi secara fasih. Situasi penggunaan bahasa ini terjadi ketika anak tersebut sementara belajar dan ayahnya lagi bekerja atau memotong kayu. Oleh sebab itu ayahnya dengan spontan menyuruh anaknya untuk mengambil parang tersebut untuk memotong kayu. Penggunaan BMA biasanya digunakan ketika penutur dalam hal ini orang tua menjelaskan kepada anaknya tekait hasil belajar yang diperoleh. Percakapannya dituturkan dalam kalimat berikut :

(I): Oci, ose ni belajar apa sah di skolah sana sampe ose dapat nilai bagini 
'Oci apa yang kamu dapatkan di sekolah sehingga nilaimu jelek sekali'

(O): Seng tau bapa beta saja rajin blajar mo dong kasih beta nilai bagitu

'Ayah, aku tidak tau apa yang menyebabkan sehingga hasil yang didapat tak

sesuai yang diharapkan'.

Komunikasi berlangsung di rumah saat Ibunya baru pulang dari sekolah untuk menerima laporan pendidikan, dan komunikasi berlangsung dengan menggunakan BMA karena Ibunya menggunakan bahasa tersebut. Hal ini yang menyebabkan sehingga anaknya merespon atau menjawab dengan menggunakan bahasa yang sama. Penggunaan BYM pada ranah keluarga bagi penutur GT dengan hasil persentase $76 \%$, BMA $24 \%$ dan BI 0\%. BYM biasanya digunakan oleh penutur GT ketika mereka sedang kumpul keluarga besar untuk membicarakan tentang hal-hal yang berhubungan kekeluargaan. Percakapannya dituturkan dalam kalimat berikut :

(A): Dopi ko nim adi ane nos saf ma mumakekir iye ferne des?

'Dopi apa yang menyebabkan sehingga kemarahan terhadap adikmu belum terselesaikan'

(D) :Kumakekir iy des kole ktwak seng ber anuk nkuliah ton ntafil 'kemarahanku belum habis kerena pada saat anaku melanjutkan pendidikan ke perguruan tinggi, iya tidak memberi sepeser uang untuk membantu biaya perkuliahan anakku'.

Komunikasi berlangsung saat salah satu anggota keluarga meninggal yang menyebabkan berkumpulnya keluarga besar untuk membahas tentang pemakaman. Setelah usai pemakaman keluarga pun berkumpul untuk membahas kembali apa yang menyebabkan sehingga terjad keretakan-keretakan dalam keluarga besar. Penggunaan BYM pada ranah keluarga bagi penutur GL dengan hasil persentase 100\%, BMA 0\% dan BI 0\%. Biasanya dalam kehidupan tiap hari, GL lebih banyak menggunakan bahasa Yamdena untuk berkomunikasi antaranggota keluarga saat berada di rumah. Percakapannya dituturkan dalam kalimat berikut :

\section{Suami : Ler yei tam safe? \\ 'apa yang kita makan hari ini? \\ Istrinya : Tam arumit nenis inar \\ 'hari ini kita makan kombili dan ikan'.}

Komunikasi berlangsung ketika penutur dalam hal ini seorang ayah yang lagi menanyakan kepada istrinya tentang apa yang nantinya kita makan hari ini, komunikasinya terjalin dengan baik dan lancar karena suami dan istri ini sama-sama memahami BYM dan berasal dari desa yang sama. Hal ini menunjukan bahwa orangorang tua masih tetap bangga menggunakan BYM sebagai bahasa pertama dan tetap melestarikannya kepada generasi-generasi penerus. Sedangkan penggunaan BMA dan BI pada bidang ini sama sekali tidak digunakan oleh GL karena hasil persentase yang didapat oleh kedua bahasa $0 \%$.

Penjelasan di atas akan dianalisis dengan menggunakan teori ranah karena peristiwa komunikasi terjadi di suatu tempat yaitu rumah. Dianalisis juga dengan teori pergeseran dan pemertahanan, pergeseran bisa dilihat terdapat pada generasi muda dengan hasil persentase yang sangat memprihatinkan, pada hal mereka adalah generasi penerus yang harus tetap menggunakan bahasa pertama mereka namun justru sebaliknya. Sedangkan pemertahanan terlihat pada GT dan generasi lanjut. Tak bisa dipungkiri bahwa pemertahanan BYM terdapat pada kedua generasi yang sudah 
disebutkan di atas, karena mereka lebih suka menggunakan BYM untuk berkomunkasi dibandingkan BMA dan BI. Hal ini menunjukan bahwa situasi kebahasaan yang terlihat ada ranah keluarga adalah BYM, karena bahasa tersebt merupakan bahasa pertama yang harus dilestarikan dan diwariskan kepada generasi selanjutnya agar tidak hilang begitu saja.

\section{Kekerapan Penggunaan BYM pada Ranah Keluarga}

Kekerapan penggunaan BYM pada ranah keluarga bagi penutur GM dengan hasil persentase 10\%, BMA 90\% dan BI 0\%. BYM sering sekali digunakan oleh generasi muda ketika mereka berada di rumah saat berkomunikasi dengan para anggota keluarga baik antara ayah dan anak, ibu dan anak bahkan antarsesama anak yaitu kaka dan adik. Berikut adalah percakapan antara kaka dan adik yang dituturkan dalam kalimat di bawah ini :

(K) : Adik pwinjam ko nim pena fukit

'Adik bolehkah saya meminjam penamu'

(A): Mwal na dalim ta sane kak

'Pena saya berada didalam tas dan boleh diambil'

(K) : Terima kasih adik

Komunikasi yang terjadi antara kaka dan adik ini di rumah ketika mereka sementara belajar bersama. Peristiwa komunikasi berjalan dengan lancar dan baik karena penutur menanyakan dengan BYM dan adiknya pun membalas dengan bahasa yang sama. Perakapan di atas merupakan kalimat-kalimat pendek yang sering sekali digunakan oleh GM untuk berkomunikasi antarsesama, jika percakapnya terjadi dengan pernyataan yang sudah panjang mereka tidak lagi menggunakan BYM dan biasanya bahasa yang digunakan untuk pernyataan-pernyataan panjang adalah BMA. Penggunaan BMA digunakan oleh generasi muda ketika berkumpul bersama untuk bercerita tentang keadaan sekolah atau saat belajar. Percakapannya dituturkan dalam kalimat di bawah ini

(A) : Semi, beso katong jam matematika dari ibu sapa e?

'Apakah anda tahu pelajaran matematika di asuh oleh ibu siapa?

(S) : Ose ni pung ibu sendiri bisa lupa tu, ibu Alin to

'Ibu Alin yang mengasuh pelajaran matematika'.

(A) : oo iyo e, beta bisa lupa skli tu

'Maaf saya sudah melupakan'.

Peristiwa komunikasi yang terjadi antara penutur dan lawan tutur di atas, ketika (A) sementara berada di rumah dan (S) pun menghampiri untuk bercerita tentang keadaan di sekolah yang berhubungan dengan jam peajaran mereka. Percakapan berlangsung dengan menggunakan BMA dikarenakan mereka tidak bisa menyampaikan maksudnya dengan menggunakan BYM karena kurang fasih, sehingga peranan BMA biasanya digunakan dalam situasi yang di gambarkan di atas. Penggunaan BYM pada ranah keluarga bagi penutur GT dengan hasil persentase 75\%, BMA 25\% dan BI 0\%. BYM biasanya digunakan oleh GT ketika mereka duduk bersama di rumah untuk mebicarakan tentang suatu hal. Percakapnnya dituturkan pada kalimat di bawah ini :

(I.Y) : Bapak Alfons ding mei nfalik fete kokol yei trapat naskol nenis dewan guru? 
'Bapak Alfons, anak saya memberitahukan kapada saya bahwa besok ada rapat bersama antara orang tua murid dan dewan guru di sekolah. Oleh sebab itu saya kemari untuk memastkan apakah informasi yang disampaiakn itu benar atau tidak?

(B.A) : Nfalik betun ndre, jad kokol nei trapat bersama ma tatanuk nmengenai dedekar yei fete rdenger hasil yei fermbei

'Betul Ibu, kalau besok ada rapat bersama antara orang tua dan dewan guru untuk sama-sama membahas mengenai hasil ujian yang sebentar lagi akan diumumkan.

(I.Y) : Monin Pa Alfons, nose kokol betno yak ti skol

'Baik Bapak Alfons, besok saya akan pergi ke sekolah untuk menghadiri rapat yang dimaksud.

Komunikasi di atas yang terjalin antara (I.Y) dan (B.A) sebagai lawan tutur terjadi di rumah ketika penutur dalam hal ini (B.A) baru pulang dari sekolah. Maksud kedatangan penutur ke rumah lawan tutur untuk mengecek informasi yang disampaikan oleh anaknya, dan memastikan apakah informasi tersebut benar atau tidak. Penutur menanyakan dengan menggunakan BYM sehingga lawan tutur pun meresponya dengan menggunakan bahasa yang sama karena keduanya berasal dari desa yang sama sehingga penyampaikan maksudnya dan tujuan kedatangannya dapat dipahami oleh lawan tutur dengan baik. Penggunaan BYM pada ranah keluarga bagi penutur GL dengan hasil persentase $90 \%$, BMA $10 \%$ dan BI 0\%. BYM biasanya digunakan oleh pentur GL ketika mereka berada di rumah seperti komunikasi antara suami dan istri. Percakapannya dituturkan dalam kalimat berikut di bawah ini :

(S) : kokol kit ti letar ma tal anwat ndre

'Besok kita akan pergi ke kebun untuk mengambil makanan'.

(I): Nose tatar tina nbal ma ti tal anwat ketin bersir kole sir to ni anwat

'Kita akan pergi tetapi harus memanggil Tina (anak mereka) untuk pergi bersama mengambil makanan karena mereka juga tidak punya makanan.

(S) : Nose mutar sir ndre

Nanti anda yang memanggil dia'.

(1) : oo, nose betno kfalik ber sir

'Saya akan sampaikan kepada dia'.

Peristiwa komunikasi antara suami dan istri terjadi di rumah saat mereka lagi duduk santai menikmati hidangan sore. Tiba-tiba suami menanyakan kepada istri dengan menggunakan BYM kalau besok mereka akan ke kabun untuk mengambil makanan untuk dimakan selama seminggu berjalan, dengan spontan istrinya menjawab dengan menggunakan bahasa yang sama bahwa kita akan pergi namun harus memanggil anak mereka yang sudah berkeluarga untuk pergi bersama-sama dikarenaan mereka juga kehabisan makanan. Komunikasi berlangsung antara penutur dan lawan tutur berjalan dengan baik karena keduannya sama-sama memahami BYM dan sangat fasih dalam penyampaiannya. Untuk menganalisis penggunaan bahasa oleh masyarakat yang berada di Desa Arui Das pada ranah keluarga yang sudah dipaparkan di atas, peneliti menggunakan teori ranah atau domain serta pemertahanan dan pergeseran. Ranah atau domain digunakan untuk menganalisis karena peristiwa komunikasi terjadi atau berlangsung antara penutur dan lawan tutur saat mereka berada di rumah dalam hal ini ranah keluarga. Sedangkan teori pemertahanan digunakan pada ranah keluarga karena terdapat adanya pemertahanan bahasa pertama oleh penutur generasi transisi dan genrasi 
lanjut. Hal ini menunjukan bahwa kedua generasi tersebut sering sekali menggunakan BYM untuk berkomunikasi antarsesama anggota keluarga baik antara suami dan istri atau sesama anggota masyarakat lainya. Jika dibandingkan dengan GM yang merupakan penerus budaya daerah dalam hal ini BYM yang merupakan warisan yang harus dilestarikan dan digunakan, justru sebaliknya, hasil yang didapat memperlihatkan terjadinya pergeseran bahasa pertama yang merupakan bahasa ibu mereka.

\section{Kekerapan Penggunaan BYM pada Ranah Keluarga}

Kekerapan penggunaan BYM pada ranah keluarga bagi penutur GM dengan hasil persentase 22\%, BMA 68\% dan BI 10\%. BYM biasanya digunakan oleh penutur GM ketika mereka sementara berada di rumah. Percakapannya dituturkan dalam kalimat berikut :

(K) : Adik mwal yak ning hp ne fukit?

'Bolehkah anda mengambil hp saya?

(A) : Nambin mbei

'Hp anda dimana'

(K) : Na das mej ane

'Hp saya ada di atas meja'

(A) : Yei nde tat

'Apakah ini h panda atau tidak'

(K) : Nei ndre

'itu hp saya'.

Komunikasi yag terjalin antara kakak dan adik terjadi saat mereka baru selesai makan bersama dengan keluarga dan tidak disengaja hp kakanya tertinggal di atas meja sementara kakak sudah berada di ruang tamu sambil menonton tv. Akhirnya kakak meminta tolong kepada adiknya untuk mengambil hp tersebut dengan menggunakan BYM dan adiknya merespon dengan menggunakan bahasa yang sama namun dalam bentuk kalimat yang pendek-pendek. Penggunaan BMA digunakan ketika mereka sementara belajar bersama di rumah. Percakapannya dituturkan dalam kalimat berikut :

(A) :Kaka tolong biking beta tugas matematika ini dolo barang beta seng mengerti?

'Apakah anda bisa membantu saya mengerjakan tugas matematika?

(K) : Biking apa la ose seng mengerti

'Apa yang menyebabkan sehingga anda tidak paham dengan tugas yang diberikan?

(A) :Barang tadi ibu mengajar paling cepat jadi beta seng mengerti

'Cara mengajar yang diterapkan oleh ibu terlalu cepat sehingga saya tidak paham'

(K) :Beta bantu, tapi lain kali kalau ibu mengajar cepat itu disampaiakan agar ibu tersebut tau

'Saya akan membantu untuk mengerjakan tugas anda, namun lain kali anda harus berani menyampaiakn kepada ibu tersebut bahwa cara (A) :Iyo mengajarnya diperlambat agar kita bisa memahami apa yang disampaikan.

'Iya'. 
Komunikasi tersebut terjadi ketika penutur merasa kebingungan dalam mengerjakan tugas yang diberikan, sehingga meminta pertolongan kepada kakanya yang sementara duduk menonton televisi dengan menggunakan BMA. Maka dengan segera kakanya memberikan amanat yang nantinya disampaikan jika hal tersebut terulang kembali, sambil mengerjakan tugas adiknya yang akan dikumpulkan besok saat di sekolah. Sedangkan penggunaan BI digunakan ketika penutur dan lawan tutur lagi berada di rumah sambil melatih diri untuk membacakan naskah undang-undang dasar saat upacara nanti. Percakapannya dituturkan dalam kalimat berikut :

(K) : Tolong ambilkan saya segelas air?

(A) : Iya kakak.

Komunikasi singkat antara kakak dan adik ini terjadi di rumah, ketika kakanya lagi duduk di depan rumah sedang mencicipi cemilan. Sesudah itu kakak merasa dahaga dan akhirnya sepenggal kalimat yang diujarkan dengan menggunakan BI kepada adiknya terkait maksud yang sudah dipaparkan pada percakapan di atas dan adiknya pun merespon dengan sebuah kalimat pendek dalam bentuk bahasa yang sama. Penggunaan BYM pada ranah keluarga bagi penutur GT dengan hasil persentase 67\%, BMA $32 \%$ dan BI 1\%. BYM biasanya digunakan oleh GT ketika mereka sementara kumpul keluarga. Percakapannya dituturkan dalam kalimat berikut:

(Y) : Lisa ko nim saum nal gaji bermama lo nde tat?

'Apakah suami anda sudah memberikan sebagian dari gajinya kepada Ibu atau belum?

(S) : To nal fukit jad ko mfualik ber iy

'Dia belum memberikannya jadi tolong sampaikan kepadanya'

(Y) : Nose kfualik ber iy

'Saya akan sampaikan kepadanya'

(S) : Noflan ko motak

'Menurut anda saja'

Komunikasi di atas terjadi ketika mereka ada dalam kumpul keluarga bersama di rumah tua sekaligus menjenguk ayah dan ibu. Percakapan terjadi ketika Yani melihat suami dari adiknya yang bernama Soni turut hadir, maka dengan spontan Yani menannyakan kepada adiknya terkait maksud yang sudah dipaparkan di atas dengan menggunakan BYM agar suami dari adiknya tidak memahami apa yang sedang mereka bicarakan. Sesudah itu, adiknya merespon dengan menggunakan bahasa yang sama untuk memperlancar percakapan yang sedang terjalin. Sedangkan biasanya BMA digunakan ketika Ayah berbicara dengan istri dari anaknya laki-laki. Percakapan tersebut dipaparkan dalam kalimat berikut :

(A) : Esty, Bapa Cuma mau bilang kalau dong dua su kaweng ini jadi kedepan itu bae-bae saja?

'Kalan berdua sudah bersama-sama dalam ikatan pernikahan, sehingga harap Bapak kedepan kiranya hidup kalian semakin dewasa.

(E.Menantu) : Iyo Bapa 'Iya Ayah'

(A) : Kalau ada masalah itu panggel dia maso dalam rumah beru bicara bae-bae, mo jang bicara atau bakali dia di luar lalu orang dengar maka dong tau kamong dua masalah smua 
'Ketika ada keretakan dalam rumah tangga kalian maka harus dibicarakan secara baik-baik bukan dengan mengumbar-umbar sehingga para tetanggapun mendengar.

(E) : Iyo Bapa, nanti Ayah bicara par di alai supaya dia juga tau to 'Saya sudah paham dengan apa yang Ayah sampaikan, jadi nanti disampaiakan juga kepada anak Ayah sehingga dia juga memahami.

(A) : Iyo, nanti bapa bilang di di alai

'Iya Nak, Ayah akan sampaiakan hal yang sama kepadanya.

Komunikasi tersebut terjadi ketika anak laki-lakinya membawa istrinya pergi ke rumah tua untuk bertemu dengan kedua orang tua. Setelah tiba di rumah mereka dijemput oleh kedua orang tua sambil duduk di ruang tamu, maka dengan spontan Ayah menyampaikan maksud tersebut berupa amanat kepada menantu dengan menggunakan BMA, karena menantunya berasal dari desa lain yang sudah jelas bahasa pertamanya berbeda dan tidak mungkin ayah menanyakan atau menasehatinya dengan menggunakan bahasa daerah. Ayah pun mengetahui hal itu sehingga dalam menasehati menantu tersebut ayah menggunakan BMA agar menantunya memahami apa yang disampaikan dan menantu merespon dengan menggunakan bahasa yang sama. Sedangkan penggunaan BI biasanya digunakan ketika penutur menanyakan suatu maksud kepada keluarga. Percakapannya dituturkan dalam kalimat berikut :

(R) : Kapan kita akan pergi ke pantai?

(R) : Setelah saya libur nanti.

Komunikasi di atas terjadi ketika mereka sementara duduk bercerita, tiba-tiba dengan spontan Relya mengeluarkan kalimat pendek dengan menggunakan BI sambil menanyakan sesuatu kepada Rendi, maka Rendi dalam hal ini sebagai lawan tutur merespon dengan sepenggal kalimat yang sudah dipaparkan di atas sebagai jawaban atas pertanyaan yang disampaiakan oleh Relya. Percakapannya terjadi dengan menggunakan bahasa tersebut secara spontan. Penggunaan BYM pada ranah keluarga bagi penutur GL dengan hasil persentase 84\%, BMA 16\% dan BI 0\%. BYM biasanya digunakan oleh penutur GL dalam ranah keluarga seperti percakapan antara ayah dan ibu yang dituturkan dalam kalimat berikut :

(A) : Kit ning dedkar yei sir arwal low

'Anak-anak kita sekarang sudah besar'

(I) : Fernei ndre

'Begitulah seperti yang ayah lihat'

(A) : Nose mumtorin nenis sir ane, mutanuk ber sir ma kele ros fakin

'Jika anda duduk bersama-sama dengan mereka, aka harus memberikan nasehat agar mereka tidak melakukan hal-hal yang tidak diinginkan'

(1) : Bias kfualik bersir ndre

'Saat duduk bersama-sama, saya selalu menasehati mereka'

Komunikasi terjadi di rumah ketika Ayah dan Ibu lagi duduk bersama untuk melihat pertumbuhan anak-anak mereka nantinya kedepan. Sambil duduk Ayah dalam hal ini sebagai penutur menyampaikan maksudnya yang terdapat pada percakapan di atas kepada ibu dengan menggunakan BYM dan Ibu merespon dengan menggunakan bahasa yang sama untuk memperlancar percakapan yang sedang berlangsung. Sedangkan penggunaan BMA biasanya digunakan ketika penutur sedang berbicara dengan orang lain (tamu) yang hendak berkunjung ke rumah. Percakapannya dituturkan dalam 
(T) : Slamat pagi bapa, jang marah katong su ganggu pagi-pagi?

'Selamat pagi Bapak, maaf kami sudah mengganggu waktunya di pagi hari?

(T.R) : slamat pagai juga, seng apa-apa. Boleh tau nyong dong kesini untuk apa? 'Selamat pagi juga. Apa yang terjadi sehingga anda kemari di rumah saya?

(T) : Katong kesini mau ambil data keluarga bapa, barang mau rekap jumlah penduduk

'Kami kesini mengambil nama-nama anggota keluarga karena akan direkap jumlah penduduk desa secara keseluruhan'

(T.R) : Oo iyo nyong

'Iya nyong.

Komunikasi di atas terjadi ketika di pagi hari ada seorang Bapak yang lagi duduk di teras rumah sementara menikmati hidangan pagi yang telah dibuat oleh istrinya. Tiba-tiba, Bapak tersebut kedatangan tamu dari kecamatan yang hendak berkunjung untuk suatu maksud yang sudah dipaparkan pada percakapan di atas. Penutur menyapa lawan tuturnya dengan menggunakan BMA dan akhirnya percakapan pun terjadi antara mereka dengan menggunakan bahasa tersebut. Sedangkan penggunaan BI oleh GL sama sekali tidak digunakan.

Penjelasan di atas akan dianalisis dengan menggunakan beberapa teori yaitu teori ranah atau domain, pergeseran dan pemertahanan. Menurut Fishman (dalam //ejournal.undip.ac.id>download) mendefenisikan ranah sebagai gambaran abstark sosiobudaya dari topik komunikasi, atau hubungan timbal balik antarkomunikator dengan tempat terjadinya peristiwa komunikasi sesuai struktur sosial lapisan masyarakat. Teori tersebut sejalan dengan penjelasan di atas terkait peristiwa komunikasi yang terjadi antara penutur dan lawan tutur ketika mereka sementara berada di rumah yang sedang membicarakan tentang suatu hal yang sudah dijelaskan pada masing-masing percakapan yang terjadi oleh GM, GT dan GL di atas. Sedangkan teori pergeseran menurut Chaer dan Agustina (2010 : 142) adalah masalah penggunaan bahasa oleh seorang penutur atau sekelompok penutur yang biasa terjadi sebagai akibat perpindahan dari satu masyarakat tutur ke masyarakat tutur yang lain. Oleh sebab itu, maka pergeseran bahasa pertama dalam hal ini BYM yang ditemukan pada ranah keluarga terdapat oleh penutur GM yang sangat sedikit dari mereka yang masih tetap menggunakan BYM untuk berkomunikasi antaranggota keluarga sementara selebihnya mereka lebih suka dan bangga menggunakan bahasa kedua dalam hal ini BMA lebih banyak untuk berkomunikasi dibandingkan bahasa pertama mereka. Fenomena di atas berbeda dengan GT dan GL yang masih setia dan bangga menggunakan bahasa pertama mereka untuk berkomunikasi antaranggota keluarga dibandingkan BMA yang merupakan bahasa kedua.

\section{KESIMPULAN}

Berdasarkan hasil penelitian terhadap penggunaan bahasa Yamdena di Pulau Yamdena Bagian Timur Kabupaten Kepulauan Tanimbar Provinsi Maluku. Dapat diambil kesimpulan sebagai berikut : Masyarakat di Pulau Yamdena khususnya di Desa Arma, Arui Bab, dan Arui Das pada dasarnya dalam interaksi menggunakan dua bahasa yaitu BYM dan BMA. Hal ini terjadi karena masyarakat tutur yang berada di Pulau Yamdena untuk GT dan GL lebih dominan menggunakan BYM untuk berkomunikasi 
dalam kehidupan sehari-hari, sedangkan untuk GM, mereka hanya mengerti maksud yang di sampaikan namun untuk meresponnya mereka lebih dominan menggunakan BMA. Fenomena di atas berbeda dengan masyarakat tutur yang berada di Desa Sifnana yaitu dalam melakukan kegiatan setiap hari, mereka menggunakan tiga bahasa yaitu BYM, BMA dan BI.

Pada ranah keluarga memperlihatkan ada dua bahasa yang digunakan oleh masyarakat tutur yang berada di Desa Arma, Arui Bab dan Arui Das yaitu BYM dan BMA. Meskipun ada bahasa kedua yaitu BMA. Bahasa yang lebih dominan pemakaiannya dalam ranah keluarga adalah BYM. Fenomena di atas berbeda dengan masyarakat Tutur yang berada di Desa Sifnana yang menggunakan tiga bahasa dalam melakukan kegiatan sehari-hari yaitu BYM, BMA dan BI. Meskipun terdapat dua bahasa lainnya yaitu BMA dan BI, tetapi yang lebih dominan dipakai untuk berkomunikasi adalah BYM

Berdasarkan penjelasan di atas dapat diambil kesimpulan bahwa, secara umum penggunaan BYM yang paling bergeser atau relatif rendah terdapat pada penutur yang berada di Desa Arma dan Sifnana dengan hasil persentase masing-masing 34\%, dan yang relatif tinggi terdapat pada masyarakat tutur yang berada di Desa Arui Das dengan hasil persentase $46 \%$ dan diikuti oleh masyarakat tutur yang berada di Desa Arui Bab. Sementara berdasarkan ranah, pergeseran BYM yang relatif tinggi terdapat pada ranah keluarga dan diikuti oleh ranah ketetanggaan dan yang relatif rendah terdapat pada ranah pendidikan.

\section{DAFTAR PUSTAKA}

Aslinda, dan Syafyahya. 2007. Pengantar Sosiolinguistik. Bandung : Refika Aditama.

Chaer, Abdul. Agustina, Leonie. 2010. Sosiolinguistik Perkenalan Awal. Jakarta : Rineka Cipta.

Moleong, Lexy J. 2017. Metodologi Penelitian Kualitatif. Bandung : Remaja Rosdakarya

Sugiyono. 2015. Metode Penelitian pendidikan Pendekatan Kuantitatif, Kualitatif, dan $R \& D$. Bandung : Alfabeta

Idayuanggra.blogspot.co.id./2018/10/03/konsep/pemertahanan/bahasa.html?m=1.

Diakses pada tanggal 05 mei 2018.

Taber, Mark, (Eds). 1996. Atlas Bahasa dan Maluku.Ambon. SIL

Pusat Pengkajian dan Pengembangan Maluku Universitas Pattimura. Lewier, Mariana dan R. A da Costa. 2012. "Suku Bangsa dan Bahasa Tanimbar". Laporan Hasil Penelitian Balai Pengkajian Nilai Budaya Provinsi Maluku. 